\title{
Storage Facilities, Workspace and Conservation and Preparation Services from the Foundation of the Ethnographic Museum to This Day
}

- The text provides an overview of the changes made inside the Museum in terms of the positioning of the permanent exhibition and the extension of storage facilities and workspace from the foundation of the Museum in 1919 to this day. The building in which the Ethnographic Museum is located is one of a few buildings in the city of Zagreb that has been built for a specific museological purpose. Nevertheless, from its inception, its structure and the interior design concept were inadequate for the performance of all the museum activities and hence repurposing and room extensions have been performed several times.

Keywords: Ethnographic Museum (Zagreb) permanent exhibition, storage facilities, conservation and preparation service

\section{INTRODUCTION}

The building of The Trade and Crafts Museum, in which in 1919 the Ethnographic Museum was located upon its foundation, was inadequate for the performance of the activity and the development of the Museum ${ }^{1}$ due to its structure and interior design concept. Inadequacy of the premises was primarily evident in the shortage of work-

1 The building was constructed from 1902 to 1903 to provide exhibition space for the Chamber of Trades and Crafts. 
space for expert and technical staff, as well as in a lack of premises intended for the storage of museum collections, which prevented the expansion and modern design of the Museum. Such a situation resulted in necessary changes and building extensions that have been performed several times over the last one hundred years of the existence of the Museum. The adaptation of the building performed from 1968 to 1972 that, among other things, ensured also workspace for the staff in charge of conservation of museum collections, resulted both in a gradual increase in the number of members of expert staff and the level of qualifications held by the employees in the Conservation and Preparation Department. During the first one hundred years of Museum activity, from employees in charge of textile material conservation and staff "dexterous in carpentry", we have reached the level at which the most challenging conservation and restoration interventions are being performed inside the Museum. Irrespective of the fact that the building does not provide adequate space for the storage of the collections and that it does not ensure stable microclimate conditions required for the existence and sustainability of museum collections, systematic implementation of measures of preventive conservation and restoration is intended to offset the negative effects of inadequate conditions in the Museum building.

\section{STORAGE FACILITIES AND WORKSPACE OF THE ETHNOGRAPHIC MUSEUM}

During the first decades after the foundation of the Museum several changes were made in the permanent exhibition, while workspace and storage facilities were relocated once. It was only upon the adaptation of the building during the period from 1968 to 1972 and upon the fifth floor addition in 1989 that adequate facilities were provided for the storage of the objects, as well as the workspace for expert and technical staff. All the significant changes that enabled the unimpeded activity of all the museum services have been chronologically listed and described hereinafter.

\section{THE PERIOD FROM 1919 TO 1968}

Upon the foundation of the Ethnographic Museum in Zagreb in 1919, all the existing ethnographic collections from the National Museum were brought together with the textile collection by Salamon Berger and located in the building of The Trade and Crafts Museum (Gjetvaj 1989: 17-19). During the first several years after its foundation, the museum collections comprised of around 20,000 objects ${ }^{2}$ and upon inventorying and cataloguing of the existing objects, the objects started being collected through a network of the Friends of the Museum ${ }^{3}$ and they started being prepared for exhibition.

2 Museum collections currently comprise of around 70,000 objects.

3 "A network of the Friends of the Museum was established, striving to both facilitate and accelerate the work in connection with collecting objects. They collected objects and donated them to the Museum out of love for traditional folk heritage. Upon the proposal of the Museum Administration, the Commission for Education and Religion issued the order on the foundation of the "Service of the Trustees of the Ethnographic Museum in Zagreb" (Gjetvaj 1989: 20). 
The first permanent exhibition was opened to the public on the $19^{\text {th }}$ June 1922. It was staged in the left wing of the ground floor section of the building and on the first floor, while the staff workspaces were located in the right wing on the ground floor of the building. They comprised of the following:

“The textile expert's room, the museum draughtsman's room, a storage for still cameras, treasure chests, mannequins, etc., a room for cleaning, disinfection and restoration of museum objects, a proportion of the storage, a partition for the director and the library, the administration and the library, a partition for the custodian of the collection and the library, a room for film processing, the museum janitor's flat and cabinets of the committee for conservation of popular antiquities" (Ibid.: Addendum 1).

The first changes in the permanent exhibition were made both in 1934 and in $1935^{4}$ during which also the members of the museum staff were relocated. The permanent exhibition was located in the right wing and a part of the premises in the left wing on the ground floor of the building, as well as the entire first floor of the building, while the workspace that comprised of “the Director's office, the Secretary's office, the draughtsperson's room, expert staff department, the museum janitor's flat and a film processing room" (Ibid.: Addendum 5) was located in the southern part of the left wing of the building facing the street. A proportion of storage facilities was located in the basement (for objects made of wood, ceramics, textile and leather), while the largest proportion of textile objects was stored in the cabinets that, together with the Carpenter's Workshop, were located in the room by the courtyard in the left wing of the building. The space adjacent to the Carpenter's Workshop ${ }^{5}$ was intended as a storage for carpets, wool weaves and the Jewellery Collection and it also included the preparator's workspace (Gjetvaj 1973b: 20). Shortly after these changes had been made, during the period ranging from 1939 to 1941, the basement in the southern part of the building, which was also used as a storage for objects, was also renovated. At the beginning of the World War II in 1941, all the first class objects were stored in special treasure chests and placed in the shelter outside the museum building, while the remaining objects were also stored in treasure chests and placed in the basement. When the war ended, the work on the evacuated objects started, as well as their preparation to be yet again exhibited in the permanent exhibition of the Museum (comp. Gjetvaj 1989: 24).

\section{THE PERIOD FROM 1968 TO 1972}

Unfavourable conditions in which museum activity was performed, due to a shortage of space and the deterioration of the building (Gjetvaj 1973b: 20-21), resulted in the need for adaptation of the building, which was performed during the period from

4 Changes in the permanent exhibition were made in 1946 when Marijana Gušić assumed office of the Museum Director. On that occasion, she provided a new concept of the permanent exhibition in co-operation with museum experts.

5 At the beginning of the 1980's a proportion of the previously mentioned premises became the ownership of the Croatian Chamber of Economy, while the storage facilities for the headwear and the Collection of Weapons and Jewellery occupied the remaining section. 
1968 to 1972 . The preliminary design of the adaptation of the museum building was provided by the architect Aleksandar Freudenreich on a voluntary basis. On that occasion, the existing rooms were repurposed and new ones were constructed, through which workspace was separated from the exhibition space and space was provided for storage facilities and preparation workshops.

The fourth floor was added through building adaptation on which the Textile Preparation Workshop was located in the right wing of the building. A balcony was added adjacent to the workshop with an exit to the flat roof terrace (which enabled seasonal aeration and cleaning of textile), while a lift was mounted for the transfer of heavy objects between the balcony and the rooftop terrace. Textile storage rooms were located in the attic section of the building facing the street which were accessed from the temporary exhibition hall, positioned between the Textile Preparation Workshop and the left wing of the building.

The refurbishment of textile storage facilities ensued upon the completion of construction work. The equipment for storage facilities was made in accordance with the plans for each specific collection and in co-operation with the curator in charge of the collection in question. The storage facilities were divided into eight units equipped with fitted cabinets with many drawers, while under the slope of the roof there were fitted cabinets with sliding doors. The objects were separated inside the storage facilities in accordance with systematised collections and stored in accordance with both the type of material and the type of objects.

The storage facility intended for the Collection of Wool Weaves and Carpets ${ }^{6}$ was located next to the Textile Preparation Workshop, in a split-level room in which the objects were grouped in accordance with the regions and placed on the shelves. The storage facilities intended for upper body garments made of cloth, fur and leather were also located next to the Textile Preparation Workshop. They were equipped with fitted split-level cabinets in which the objects were stored on hangers. On the other side of the temporary collection hall, there was a section for the storage facility intended for objects in connection with customs. The cabinets with glass doors contained toys, objects made of straw and casts of bread, while carnival masks were hanged in the cabinet secured with special holders. The storage facilities for small wooden objects were separated from the other wooden objects in the area located on the third floor in the right wing of the building. ${ }^{7}$ A section of the storage facility was separated with a high cabinet from the curators' workspace. The latter cabinet provided a storage for wooden shepherd's cup, wooden containers for carrying a scythe stone for sharpening a scythe, wooden boxes for razors and other boxes, to name a few, while opposite them, cabinets made primarily for this specific purpose provided a storage for distaffs (comp. Gjetvaj 1973a: 17).

6 Currently the storage of the Collection of Rugs and Carpets.

7 It is currently a storage facility used for the Easter Eggs Collection, Christmas Nativity Set Collection, The Collection of Picture Postcards and Congratulations Cards, The Collection of Musical Instruments, The Collection of Musical Instruments by Franjo Ksaver Kuhač, the Collection of Decorated Pumpkins and Distaffs from the Collection of Tools and Accessories for Textile Processing. 
The storage facility intended for the Collection of Headwear, Jewellery, Weapons and Musical Instruments was located next to the Lecture Hall on the ground floor of the building, in a room that upon adaptation was transformed into a split-level room. The Collections of Jewellery and Weapons were located in a fitted locker on the lower storey (Fig. 1), while the Collections of Headwear and Musical Instruments were located on the upper storey. They were stored in the existing cabinets (Ibid.: 18).

Illustrative objects were located in the storage facility on the first floor in the right wing of the building. It was equipped with metal shelves inside of which there were paintings on glass and oil paintings on canvas depicting folklore topics. Moreover, photocopies of large formats and other documentary objects were included. The Collection of Non-European Cultures was located on the ground floor of the building, in a split-level room. Workspace was located at the lower level, while the storage facility was located at the upper level. The objects from the Collection of Furniture, Economy, Scale Models and Ceramics were stored in the basement storage facilities. The objects made of wood were grouped according to collections and stored on shelves made of old wooden inventory, while the ceramic objects were grouped according to geographical provenance in terms of geography and stored on newly purchased shelves. During the adaptation, the Preparation Workshop for Wood, Ceramics and Other Objects was placed in the basement.

The rooms that were located in the southern section of the building facing the yard were transformed into split-level rooms, which resulted in four floors intended as workspace. Next to the library, on the first floor, two more offices were added and sanitary facilities on each floor, in which the Directors room was located, as well as the Secretary's office, curators' offices and the documentation. In that section of the building a new staircase was constructed, which connects the rooms from the basement to the fourth floor with the exhibition hall and a lift for museum staff and transport of heavy objects. The old staircase was extended in the right wing of the building, which connects the exhibition space on the first floor with the temporary exhibition hall (comp. Gjetvaj 1973b: 21-22).

\section{9 - FIFTH FLOOR ADDITION}

After the adaption, through which the fourth floor was added on which flat roof was made, as a result of the occurrence rain flood and due to the inability to fully solve the problem in 1989, a roof addition project was developed over that section of the building. The project included the construction of additional facilities through which additional museum storage facilities covering an area of $288.86 \mathrm{~m}^{2}$ were provided and additional workspace covering an area of $102.30 \mathrm{~m}^{2}$ as well as sanitary facilities, a mechanical room and a repository. The erection of a wall on the section of the building facing the yard and the construction of the roof structure enabled unhindered passage along the central part of the premises and storage of objects along the load-bearing walls. The latter resulted in fully functional premises for the storage of objects and those that could be used as office space (comp. Živković 1989: 2). The addition of the attic partially disburdened the storage facilities located in the basement, as the Collection 
of Pottery (Fig. 2), a proportion of the Furniture and Household Objects Collection and a proportion of a Collection of Traditional Economy were transferred to the fifth floor.

\section{THE PERIOD FROM 1991 TO 1995}

At the beginning of the Croatian War of Independence, the objects from the permanent exhibition were transferred yet again, albeit inside the Museum building. Mannequins in traditional national costumes from the permanent exhibition of traditional Croatian national costumes were located next to the storage facilities of headwear, weapons and jewellery. The objects from the permanent exhibition of Non-European Cultures and all the textile objects from the storage facilities were placed in treasure chests and located in the permanent exhibition space of the basic branches of the economy, while the objects from the permanent exhibition space of the basic branches of the economy were transferred into the repository on the ground floor in the right wing of the building. After the war, the permanent exhibition on the first floor was exhibited in accordance with the previously implemented concept, while the objects from the permanent exhibition of the basic branches of the economy partially remained in the repository and were partially placed in storage facilities, while the previously mentioned premises started being used for temporary exhibitions.

\section{Allocation OF THE AUXILIARY BUILDING AT 9/2 KAČićEVA STREET IN 2015}

A continuous increase in museum collections yet again highlighted a shortage of space for the storage of the objects and a poor condition of museum storage facilities, ${ }^{8}$ which provided the incentive for requesting an auxiliary building intended as museum storage facilities. In 2015, the City of Zagreb, as the founder, allocated the building at 9/2 Kačićeva Street to the Museum and a "Preliminary Design for Obtaining Special Conditions for the Reconstruction of the Building of the Ethnographic Museum located at 9/2 Kačićeva Street" was provided in 2017. The reconstruction of the building ${ }^{9}$ was intended to ensure the space required for the storage of museum objects, Restoration and Preparation Workshops, as well as administrative offices. Moreover, the project

8 In November 2017, RE-ORG workshop (de Guichen and Matković 2017: 105 - 114) was held at the Museum through which storage facilities both in the basement and in the attic (the $5^{\text {th }}$ floor of the building) were reorganised. The objects in the previously mentioned storage facilities were stored by collections. Nevertheless, the storage facilities and the corridors, due to a shortage of storage space, were used for disposal of packaging, auxiliary construction elements from the previously held exhibitions and for the storage of ethnographic objects that were stored at the Museum after customs seizures. Against the backdrop of the situation, the objects that were used for exhibitions, lending or during museum processing, could not be returned to specific storage facilities. Through the implementation of the RE-ORG project, the storage facilities were yet again allocated their basic purpose of storage of museum collections.

9 The building premises were divided into four floors in which the following rooms were envisaged: a storage facility and an ethnothèque in the basement of the building; a storage facility, Restoration and Preparation Workshop for Wood, Ceramics, Stone and Metal, as well as space for exhibitions, lectures and workshops on the ground floor of the building; a storage facility and Textile Restoration and Preparation Workshop on the first floor of the building; offices, a meeting room, archival facilities and machinery and electrical intake room in the attic of the building (comp. Vujica 2017: 35). 
envisaged also the communication with the public through storage facilities open to the public and those intended for study, as well as through specialised programmes.

\section{RELOCATION OF VULNERABLE OBJECTS FROM TEXTILE STORAGE FACILITIES IN 2016}

Due to problems with rain flood into textile storage facilities that the Museum had faced for several years, which had escalated during prolonged periods of rain in 2015 and 2016, a decision was made to repurpose a proportion of the temporary exhibition space on the fourth floor into a temporary storage facility for vulnerable textile objects. The exhibition hall premises were partially subdivided and the objects from textile storage facilities that used to be stored in fitted cabinets located under the slope of the roof were transferred there, while the Educational Workshop, which used to be located in the antechamber of the Restoration and Preparation Workshop, was relocated to the remaining section of the hall.

\section{THE PERIOD FROM 2017 TO 2019}

At the end of 2016, the City Institute for the Protection of Cultural Monuments and Nature upheld the request for a comprehensive repair and renovation of both the façade of the Museum building and the roof. Hence, immediately before the construction work started, in April 2017 the remaining objects had to be transferred from the storage facilities on the fourth floor, as well as the objects stored on the fifth floor. Textile objects were transferred to the left wing of the permanent exhibition, which was closed, ${ }^{10}$ while the objects located on the fifth floor were partially transferred before the start of the construction work on the roof in January 2019. A section of the exhibition space on the ground floor in the right wing of the building was divided in order to provide a temporary location in which to put the previously mentioned objects.

The façade renovation work and the roof replacement, which was expected to last until mid-August 2019, greatly affected the performance of professional work and the implementation of museum programmes. The objects that had been transferred from the fourth and the fifth floor were inaccessible, while all the professional work, which was done under inadequate conditions, needed to be harmonised with the construction work. Nevertheless, all the exhibition and educational programmes were implemented and they were briefly postponed only several times.

10 In June 2018, the Committee of Experts of the Museum upheld the idea to reduce the number of the existing permanent exhibition objects that would be located in the open right wing of the building, retaining the concept of division into three ethnographic zones (the Pannonian, the Dinaric and the Adriatic). The implementation was co-ordinated by the museum advisors Vesna Zorić and Aida Brenko and the Restorer Mihaela Grčević. A total of 54 mannequins wearing traditional national costumes were exhibited, while the objects from the Lace-Making Collection were added in the remaining display cases next to the display cases with exhibited linen soft furnishings due to increased public interest. Moreover, a display case - Children's World - was designed in which traditional children's toys were placed next to the mannequins in traditional children's national costumes. 
Upon the completion of the roof replacement work, the transfer of the objects back to the fourth and the fifth floor had been envisaged after which the cleaning of the overall museum collections was required as a result of the exposure to dust particles during the previously mentioned construction work.

\section{CONSERVATION AND PREPARATION SERVICE}

Since its inception, the Ethnographic Museum has been employing staff in charge of taking care of the museum objects. The textile preparation work was performed by employees who had completed a vocational school, while wood preparators (sometimes referred to as art handlers) were primarily persons with carpentry skills. As opposed to Textile Preparation Workshop, which until the building adaptation performed in 1972 did not have any allocated facilities, repairs of wooden objects were performed in well-equipped Carpentry Workshop, located in the room facing the yard in the left wing of the building. Work on textile objects primarily included regular cleaning or aeration of objects and their storage, using mothballs, globol and pantakan. ${ }^{11}$ Wooden objects were regularly exposed to wet cleaning and, after drying, they were coated in a mixture of lamp oil, turpentine, gasoline and linseed oil ${ }^{12}$ (comp. Gjetvaj 1989: 70).

The beginning of the 1960's saw an increase in the number of expert staff members at the museum and a more effective organisation of work, which resulted in the foundation of specialist departments inside the museum. The Statute of the Ethnographic Museum in Zagreb dating back to the $14^{\text {th }}$ November 1966, besides determining the General Provisions and Tasks of the Museum, established the Internal Organisation of the Museum upon which the Conservation and Preparation Workshops with the photo lab, Drawing Workshops and Moulage ${ }^{13}$ Workshops, scale models and models became parts of Joint Technical Services of the Museum (Ibid.: 52).

After the building adaptation, through which Textile Preparation Workshop was allocated workspace and upon the re-opening of the Museum in 1972, a systematic arrangement of textile storage facilities started, through which all the objects that during the adaptation had been stored in treasure chests, were allocated and arranged into new storage facilities. Moreover, a systematic implementation of preventive conservation measures and storage started.

Upon adoption of the new Job Classification Regulation dating back to the $13^{\text {th }}$ December 1977 and based on the Statute of the Ethnographic Museum, the Conservation and Preparation Service became integrated into the Specialist and Scientific Department.

Two preparators with secondary school qualifications and an assistant preparator doing manual work in connection with the work done in the Preparation Workshop, as well as all the necessary work inside the Museum, were employed at the Preparation

11 Chemical substances used upon storage of textile objects to provide protection from pests.

12 Linseed oil with accelerators of drying that is used as impregnation for wood and in painting.

13 French moulage: the process of making moulds or casts, shaping. 
Workshop for wood, metal and other objects in the 1980's. In 1988, the Workshop was allocated new premises in the basement of the Museum, yet it was arranged, decorated and equipped only in 1995. Two restorers and a preparator are currently employed at the Workshop, who in addition to the work connected with preventive conservation and restoration of objects from collections that they are in charge with, against the backdrop of a lack of a technical service, greatly participate in technical implementation of museum programmes.

At the beginning of the 2000's, the Textile Workshop was in two occasions provided new furniture, while the equipment required for preventive conservation and restoration of objects is procured on an annualised level. The Museum currently employs two restorers and three senior preparators each of whom is in charge of specific textile collections (Fig. 3 and 4). In addition to textile objects, the Workshop is in charge of conservation of objects from the Souvenir Collection, the Collection of Children's Toys and Games, the Collection of Folk Medicine Objects, the Collection of Congratulations Cards and Picture Postcards, the Collection of Objects Related to Customs and Beliefs, the Perinić Collection and Museum Documentation.

An important segment of the activity performed by the workshops is also technical implementation of exhibitions within which all the work in connection with the objects, from preparation of objects for exhibition (cleaning, conservation and restoration) to technical implementation is done in the Departments.

\section{PREVENTIVE CONSERVATION AND RESTORATION}

Preventive conservation methods, which include proper labelling of objects, cleaning and storage, are implemented when objects enter the Museum. After an object has been allocated an inventory number at the Workshop, it is wet cleaned or dry cleaned depending on the requirements and in extreme situations it undergoes a dry cleaning using chemical solvents ${ }^{14}$ (textile objects). If the objects are infested with pests, they undergo a freezing treatment, ${ }^{15}$ and in cases in which, in addition to pests, there are also moulds and microorganisms, gamma radiation treatment ${ }^{16}$ is implemented at

14 Upon the recommendation of the Institute for Textile Chemistry and Ecology of the Faculty of Textile Technology of the University of Zagreb, dry cleaning using chemical solvents is performed at the Lemia d.o.o. dry cleaner's The upper parts of clothing made of wool brush are cleaned. Objects are cleaned in a perchlorethylene solution and a lubricating preparation is added while drying is performed at the dry cleaning machine at the temperature of $55{ }^{\circ} \mathrm{C}$. In 2017, the purchase of a Renzacci dry cleaning machine that uses alternative solvents, with the use of Total TDC2000 isoparaffinic solvent for a cleaning system with hydrocarbon solvents, enabled us to clean the objects made of materials in non-durable colours. Exclusively the objects that are in good condition from the mechanic aspect may undergo dry cleaning with chemical solvents.

15 Before undergoing a freezing treatment, the item is vacuumed in order to eliminate dust, loose fibers and the remains of pests, as well as their eggs and larvae. The item is placed in a deep-freezer for 14 days at the temperature of $-18^{\circ} \mathrm{C}$. When it has been taken out, it is left sitting on a flat surface for one day to gradually temper. Objects that undergo freezing treatment must not contain wax, glass, synthetic, varnish, bones and horns (comp. Grčević 2012: 204).

16 Radiation desinsection of objects made of textile fibres is performed in the radiation device with the dose of 2 $\mathrm{kGy}$ if the object has been infested with pests or with a slightly higher dose in case of the presence of moulds or microorganisms (Grčević 2012: 204). 
the Ruđer Bošković Institute in Zagreb. Due to the fact that there is a large amount of objects that are subject to pest infestation, the fogging of storage facilities ${ }^{17}$ is preventively implemented on an annualised level. After the cleaning, the item is labelled, packaged and stored in the storage facility. In addition to preventive conservation of newly arrived objects, members of the museum staff are involved in systematic implementation of preventive conservation measures on the objects from the collections that they are in charge of.

Museum objects vulnerable to damage present a huge challenge upon the implementation of conservation measures and storage. The latter include perishable objects (Easter eggs), fragile or easily broken objects (made of seeds, straw, paper or bird feathers) and objects made of several different materials (wood, leather, fur or fleece) such as carnival masks. In case of the previously mentioned objects, in addition to curative conservation methods (freezing treatment and/or gamma radiation treatment) the most frequently used method is one with dry cleaning by vacuuming or dusting.

The Textile Workshop made a major breakthrough in conservation and restoration of objects in the 2000's upon consultation with the Department for Textiles, Paper and Leather of the Croatian Conservation Institute ${ }^{18}$ and upon employment of staff with work experience in this field. ${ }^{19}$ Compliance with the principles of reversibility of intervention, minimum intervention, conservation of the existing condition of the object, adequate storage and documenting all the stages of work are all currently imperative during the restoration of objects. The interventions performed on individual objects are previously planned with the competent curator, the manager of the specific collection, depending on the condition of the object in question and its future use.

Documenting the performed work within the Department is a mandatory part of work within the conservation of museum collections. Reports about the preventive conservation, conservation and restoration are written on a monthly basis, while a report is written after comprehensive conservation and restoration interventions that includes photographs of all the stages of work. Starting from 2012, a computer programme was introduced for managing secondary documentation $(S++)$. Through records of interventions in a single pool entitled Conservation and Restoration Interventions about the performed preventive conservation and restoration interventions, reports are linked with records on processed museum objects through a computer programme for managing primary documentation $(\mathrm{M}++)$.

17 Fogging is performed by EKOTOURS d.o.o.

18 It is important to highlight a long-term co-operation with the Textile and Paper Department of the Croatian Conservation Institute that through sending museum staff to professional development training to museums in Great Britain transferred knowledge about methods of conservation and restoration of objects also to the Ethnographic Museum in Zagreb.

19 Marijana Najjar was employed at the Museum in 2000 after a year of work at the Department for Textiles, Paper and Leather of the Croatian Conservation Institute, while Mihaela Grčević was employed at the Museum in 2009, after ten years of work at the Department for Textiles, Paper and Leather of the Croatian Conservation Institute. Upon employment of staff members as restorers in 2009 in the Textile Preparation Workshop and in 2010 in the Preparation Workshop for Wood, Ceramics and Other Materials, the workshops in question changed their names into Textile Restoration and Preparation Workshop and Restoration and Preparation Workshop for Wood, Ceramics, Stone and Metal. 


\section{CONCLUSION}

The overview of the changes in positioning of the permanent exhibition and in terms of extension of storage facilities and workspace, as well as the description of activities performed by conservation and preparation service from the inception of the Museum to the present day were intended to highlight a whole range or problems that have been occurring during the continuous increase in museum collections and in the number of members of museum staff over the first one hundred years of Museum activity.

Against the backdrop of a shortage of space required for the performance of all the museum activities (storage, preventive conservation and restoration of objects, expert and scientific processing of museum objects, presentation of objects and educational activities), a short-term solution was provided to the problem of shortage of space through building adaptation and fifth floor addition by which the premises were repurposed and expanded.

Forty-seven years after the last adaptation, the Museum has found itself in some kind of a starting position. The outdated permanent exhibition, as well as inadequate and insufficient storage facilities and workspace, have been adversely affecting the implementation of innovative museum practices for a number of years. The project entitled "Renovated Heritage for Sustainable and Smart Development in a Hyper-Connected World" from 2016 is intended as a plan to renovate the interior of the building and for the preparation of the new permanent exhibition, while the plans concerning the storage facilities, restoration and preparation workshops and administration offices include the relocation into the reconstructed premises of the auxiliary building allocated to the Museum.

The relocation of the storage facilities and restoration and preparation workshops into the new premises would not enable a long-term expansion of collections, yet it would ensure adequate microclimate conditions for the sustainability of the collections, while larger and better equipped workshops would enable smooth running of work in terms of preventive conservation and restoration of objects.

\section{REFERENCES:}

DE GUICHEN, Gaël i Ana MATKOVIĆ. 2017. "Kako san može postati stvarnost? Izvještaj o provedenom RE-ORG projektu u Etnografskom muzeju u Zagrebu”. Etnološka istraživanja 22: $105-112$.

ECKHEL, Nerina. 1999. 80 godina Etnografskog muzeja. Zagreb: Etnografski muzej.

GJETVAJ, Nada. 1973a. "Uređenje muzejskih depoa”. Vijesti muzealaca i konzervatora Hrvatske 5: 17-19.

GJETVAJ, Nada. 1973b. "Historijat i adaptacija zgrade Etnografskog muzeja u Zagrebu". Vijesti muzealaca i konzervatora Hrvatske 5: 20-24.

GJETVAJ, Nada. 1989. “Etnografski muzej u Zagrebu - u povodu 70. obljetnice”. Etnološka istraživanja 5. 
GRČEVIĆ, Mihaela. 2012. "Restauratorsko-preparatorska radionica za tekstil: Od preventivne zaštite do konzervatorsko-restauratorskog zahvata". Etnološka istraživanja 17: 203-240.

RADAUŠ RIBARIĆ, Jelka. 1973. “Značenje i zadaci obnovljenog Etnografskog muzeja u Zagrebu". Vijesti muzelaca i konzervatora Hrvatske 5: 5-9.

VUJICA, Kristina. 2017. Idejno rješenje za ishođenje posebnih uvjeta za rekonstrukciju zgrade Etnografskog muzeja u Zagrebu na lokaciji Kačićeva 9/2. Arhiv EMZ.

ŽIVKOVIĆ, Zdravko. 1989. Idejni projekt krova nad dijelom objekta s postojećim ravnim krovom. Arhiv EMZ. 